\title{
Reflection 1: the city: a shift in mindset?
}

\author{
MCCLEAN, D.
}

2017 


\section{The city: a shift in mindset?}

\section{David McClean}

As a human phenomenon, the city occupies a central position in our collective architectural interest, ambition and vision. The importance of this pre-occupation was underscored late in 2011 at the point where, for the first time in human history, we became a predominantly urban species. As such, our cities serve as crucibles for the generation of social, cultural, and economic opportunity.

Speaking in Aberdeen in 2012, the academic Pier Vittorio Aurelli asserted that architecture maintains an ambivalent relationship with the city. The expansion of his thesis included drawing a distinction between the architecture of the city and the phenomenon of urbanisation as the consequence of systemic economic and political motive forces. However, his assertion that there are limits to the influence of the architect in the context of urban development prompts important questions about notions of the agency as a professional model in the construction of the future city, and of inter-disciplinary expertise. Important, because it seems clear that for architects not to play a significant role in urban development would position the profession on the margins of irrelevance. Important too because we need to re-evaluate our methods, relationships, and educational processes. So it is both reassuring and necessary that the work included in this book demonstrates a continuing fascination with the urban condition and its many complex dimensions, and the role that architects can play in its development, working collaboratively with others.

The magnitude of the challenge facing urban structures and communities around the world is unprecedented and daunting. On the one hand, we see the effects of rapid urban expansion in cities such as Shanghai or Mumbai, while simultaneously we are witness to the problems of economic decline in centres such as Detroit, with devastating consequences for social cohesion and the physical structure of these cities.

In the first years of this century, earth's human population exceeded 7 billion, and it is predicted that over the next 25 years this figure will grow by a further 2 billion (United Nations, 2011), the vast majority of whom will be urban dwellers (Mohan and Dasgupta, 2005). In India alone, life expectancy has increased by 26 years in the last 50, and in China by 32 years in the same period. Indeed, it is projected that urbanisation in Asia will double within 2 decades. Although to date our cities have exhibited a remarkable capacity to absorb growth, urban expansion is now occurring at an unprecedented speed, causing developmental objectives and processes to adapt and change (Cities Alliances, 2008). The global mega- city, or primate city, possesses a scale that fosters new dynamics, particular complexity, and a unique coincidence of events and processes. In developing countries, growth tends to outstrip infrastructural development, resulting in uncontrolled sprawl with inadequate servicing and unregulated property markets. Such growth positions the informal settlement as the dominant architectural and urban form, a new global vernacular. As a consequence of such expansion, many cities have an innate vulnerability due to environmental degradation along with the ingredients for social unrest such as poverty and social inequality. Hence, the global city encapsulates one of the most significant dichotomies of our time, namely the vital role that cities play as economic generators versus the deteriorating conditions within these urban structures, which if left unchecked, ultimately become self-defeating. The nature of social composition in the global city, coupled with the complex dynamics of contemporary economies, contains an inherent paradox that can be traced back to the writings of Plato; that of 'social polarisation' caused by the coexistence of significant wealth and poverty (Smith and Timberlake, 1995).

Rates of urban expansion demand new mindsets and means of delivery as governments can no longer afford to fund the infrastructural needs that are vital to civilised urban development, or to satisfying the political imperatives exerted by continued commitment to economic models of growth. The entire economic landscape is in flux, constrained by political paradigms that favour the short-term. So, how can these seismic forces of change be influenced or ordered by architectural thought? What are the visions for the future that address these questions, and according to what political or sociological ideology? 
The utopian ideals of the $20^{\text {th }}$ century as represented by the planned cities, whether realised or remaining propositional, were dominated by the social and political ideals of Modernism. Indeed, Isaiah Berlin described the utopian dream as the great project of the $20^{\text {th }}$ century. Sir Thomas More's definitive conception of utopia of 1516 was a mythical island, remote and self-sufficient in the vast expanse of the Atlantic Ocean (Ames, 1969). The characteristic of disconnection has come to typify the notion of utopia, as utopic ideas have represented our imagination of an alternative to the prevailing constraints and limitations of the society of the time. Today, acknowledgement in some quarters of a resurgent interest in the notion of utopian thinking (inter alia Pinder 2002), runs counter to what Bletter (1993) expresses as a prevailing 'absence of hope in the future'. Such despondency emanates from a belief that earlier visions are, and have proved inadequate for the complexities of the contemporary urban condition and the wider context within which it requires to be considered. Although some regard continued interest in utopian ideals as vital to critical discourse (Pinder, 2002), it would appear that the notion of transcendent reality is evaporating. Current scepticism about the utopian ideal is markedly at odds with the thinking of the $20^{\text {th }}$ century that led to the great yet flawed experimental visions of the planned city, or what Alexander termed the 'artificial city' (Mumford, 1992). Ideas such as those developed for Chandigarh or Brasilia represented the notion of 'cities of salvation' (Pinder, 2002) in direct lineage to Victorian thinking such as Howard's concept of the Garden City. Reflection on the current challenges imposed on the environment by human expansion, coupled with continual media discussion about the sustainability of our species might easily lead one to conclude that conditions have shifted thinking to a very different point. Arguably, we are ever more removed from any meaningful speculation about ideals. Equally, the fundamental motive force behind the determination of utopian dreams is the desire for some form of betterment, be it sociological, political, or technological. Although future visions may not, perhaps cannot, replicate the ideological clarity or political determination of those of the $20^{\text {th }}$ century, this desire at least remains. The optimism that the imagination and scholarly rigour brought to the realities of today by architects and academics is invaluable. These realities pose critical questions about our collective priorities, about new models, about enablement and agency, about our professions, and about education for the practitioners of the future. In other words, they pose a fascinating panoply of issues that demand thorough exploration through research. The breadth of work contained here demonstrates that many are rising to these critical challenges.

\section{References}

Ames, R. 1969, Citizen Thomas More and his Utopia, New York: Russell \& Russell

Aurelli, P. V. 2012, Architecture without quality: the project of the city and the rise of urbanization, Lecture for the Foundation for Architecture and Education at the Robert Gordon University, Aberdeen, 17 May

Bletter, R.H. 1993, Waiting for Utopia, In Cooper-Hewitt, S. Y. (ed): The Edge of the Millenium: An International Critique of Architecture, Urban Planning, Product and Communication Design, New York: Whitney Library of Design, Watson-Guptill Publications

Cities Alliance 2008, Slum Upgrading Up Close: Experiences of Six Cities, Washington: The Cities Alliance

Mohan, R. and Dasgupta S. 2005, The 21st Century: Asia becomes Urban, Economic and Political Weekly, 15 January

Mumford, E. 1992, CIAM Urbanism after the Athens Charter, Planning Perspectives, 7:4, 391-417

Pinder, D. 2002, In defence of utopian urbanism: Imagining cities after the 'End of Utopia', Geogr. Ann., 84B (3-4), 229-241

Smith, D.A. and Timberlake M. 1995, Conceptualizing and mapping the structure of the world's city system, Urban Studies, 32, 287-302

Soja, E.W. 2000, Postmetropolis: Critical Studies of Cities and Regions, Oxford: Basil Blackwell

United Nations: Department of Economic \& Social Affairs 2011, World to welcome seven billionth citizen. Accessed on 16 December at http://www.un.org/en/development/desa/news/population/world-to- welcome-seven-billionthcitizen.html 